\title{
The role of VES-13 to identify limited life expectancy in older adults in primary healthcare settings*
}

\section{O potencial do VES-13 na identificação da expectativa de vida limitada em idosos na atenção primária à saúde \\ Potencial del VES-13 para identificar la esperanza de vida limitada de adultos mayores en centros de atención primaria}

How to cite this article:

Assis DL, Chagas VO, Saulo H, Suemoto CK, Santana ANC. The role of VES-13 to identify limited life expectancy in older adults in primary healthcare settings. Rev Esc Enferm USP. 2021;55:e03743. https://doi.org/10.1590/S1980-220X2020003603743

\section{Danilo Lopes Assis ${ }^{1}$}

Virgínia Oliveira Chagas ${ }^{1}$

Helton Saulo²

Claudia Kimie Suemoto ${ }^{3}$

Alfredo Nicodemos Cruz Santana ${ }^{4}$

* Extracted from the dissertation: "Risco de mortalidade em 10 anos e vulnerabilidade em saúde em pessoas idosas na Estratégia Saúde da Família em um município de Goiás”, Escola Superior Ciências da Saúde, 2019.

${ }^{1}$ Universidade Federal de Jataí,

Unidade Acadêmica Especial Ciências da Saúde, Jataí, GO, Brazil.

${ }^{2}$ Universidade de Brasília, Departamento de Estatística, Brasília, DF, Brazil.

${ }^{3}$ Universidade de São Paulo, Faculdade de Medicina, São Paulo, SP, Brazil.

${ }^{4}$ Escola Superior Ciências da Saúde, Hospital Regional da Asa Norte, Brasília, DF, Brazil.

\begin{abstract}
Objective: To investigate the potential role of the Vulnerable Elders Survey to identify older adults with limited life expectancy in primary healthcare settings. Method: This cross-sectional study was performed in all (nine) healthcare units in Jatai, Goiás (Brazil) from July to December 2018. A sample size of 407 older adults was obtained considering an older population ( $\geq 60$ years old). Participants answered a questionnaire about sociodemographic and clinical characteristics, including the Vulnerable Elders Survey and the Suemoto index. We tested the association between limited life expectancy and the Vulnerable Elders Survey using multiple logistic regression analysis. Results: The mean age was $68.9 \pm 6.6$ yo, and $58.0 \%$ were women. The mean score of the Vulnerable Elders Survey was $2.0 \pm 2.2$, the mean score of Suemoto index was $31.5 \pm 21.1 \%$, and $17.2 \%$ had limited life expectancy. The Vulnerable Elders Survey was associated with limited life expectancy $(\mathrm{OR}=1.57 ; \mathrm{p}=<0.0001)$. Conclusion: The Vulnerable Elders Survey was able to identify older adults with limited life expectancy in primary healthcare settings and can play a role in detecting older adults who would not benefit from screening and strict control of chronic diseases.
\end{abstract}

\section{DESCRIPTORS}

Aged; Frailty; Mass Screening; Sensitivity and Specificity; Primary Health Care.
Corresponding author:

Danilo Lopes Assis

Rua Luzia Miranda, 38 - Setor Hermosa

CEP 75803-315 - Jataí, GO, Brazil

nilomed.dla@gmail.com
Received: 03/04/2020

Approved: 12/03/2020 


\section{INTRODUCTION}

Population aging is a phenomenon which represents a big challenge to healthcare systems, especially to settings with limited economic resources. According to the Statute for the Elderly in Brazil, people are considered to be elderly/older adults at 60 years of age ${ }^{(1)}$. The last Brazilian census conducted in 2010 shows that this age group already corresponds to more than $11 \%$ of the total population, accounting for more than 21 million people aged 60 and over ${ }^{(2)}$.

The aging of our population makes it essential to discuss practices in the healthcare system. Thus, the concept of health vulnerability arises, which covers aspects related to the aging and illness process, and which involve specific and multidimensional aspects ${ }^{(3)}$.

Health vulnerability refers to people's susceptibility to problems and damage to health, and older adults who are at increased risk of functional decline or death over a 2-year period $^{(3)}$. Due to its peculiarities, aging implies an increased risk for vulnerabilities which increase the chances of becoming ill and favor the occurrence of adverse clinical outcomes, impaired well-being, hospitalizations, institutionalization and death ${ }^{(3)}$.

Health vulnerability can be evaluated through a specific questionnaire, called the Vulnerable Elders Survey $\left(\right.$ VES-13) ${ }^{(3)}$. In a validation study, the VES-13 detected $32 \%$ of older adults with health vulnerability who showed an excessive risk of functional decline and mortality over a 2-year period ${ }^{(3)}$. In other studies, the VES-13 also identified older adults who more frequently used health services, those with complications and mortality after traumatic injuries and after emergency abdominal surgery, as well as older adults with functional decline and increased risk of 5-year mortality ${ }^{(4)}$. A study more recently showed the potential role of VES-13 to detect poor quality of life among older adults in Primary Healthcare (PHC) settings ${ }^{(5)}$.

Another important issue in PHC is estimating the longterm risk of mortality. Older adults with limited life expectancy (LLE), defined by a high risk of mortality ( $\geq 50 \%)$ in 10 years, may not benefit from cancer screening (colorectal, breast and prostate), or be more prone to adverse outcomes from strict diabetes control ${ }^{(6-11)}$. Thus, it is important to detect these patients in PHC in order to discuss this topic and possibly avoid unnecessary screening and aggressive treatment procedures ${ }^{(12)}$.

Accordingly, prognostic indexes can help to identify older adults with LLE. In this scenario, the Suemoto index can have a potential role considering that it was developed using data from 35,367 older people from five cohorts, including information from Brazil and Mexico ${ }^{(6)}$. Unfortunately, PHC centers in Brazil do not routinely calculate the Suemoto index. On the other hand, the VES-13 is routinely used in $\mathrm{PHC}$ centers, since its use is recommended by the Brazilian Ministry of Health ${ }^{(13)}$.

In this scenario, it is essential to perform adequate screening, diagnostic, and therapeutic approaches to reduce health vulnerability. However, this situation of vulnerability is not always identified by health service professionals due to the complexity of the factors that influence the aging process ${ }^{(3)}$. Thus, it is important to know the processes which involve aging and detect vulnerable groups in the older adult population, as they provide indicators for allocating resources to this group, reducing risks of unfavorable outcomes such as reduced functionality and death ${ }^{(5)}$.

There are still few studies in the literature which address the issue of vulnerability in the health of older adults, especially those that provide information and guidance on planning healthcare services in providing care for older adults. Therefore, this study is relevant to guide healthcare service planning ${ }^{(14)}$.

In view of the above, the objective of this study was to investigate the potential role of the Vulnerable Elders Survey to identify older adults with limited life expectancy in primary healthcare settings.

\section{METHOD}

\section{TYPE OF STUDY}

This is a cross-sectional study.

\section{SCENARIO}

The study was conducted in all PHC units (9 units) in the municipality of Jataí, in the state of Goiás, Brazil.

\section{SAMPLE DEFINITION}

The sample size for this study was calculated considering the total older adult population ( $\geq 60$ years old) in Jataí $(\mathrm{n}=$ 10,853 ), a prevalence of $50 \%$, a margin of error of $5 \%$, and a confidence level of $95 \%$, as similarly described in previous studies $^{(5,15)}$. The estimated sample size consequently consisted of 370 individuals. Finally, 10\% was added to compensate for possible missing information in the questionnaires. Therefore, the final sample size calculation comprised 407 older adults. Each participating PHC unit included the same number of individuals ${ }^{(16)}$.

The following inclusion criteria were considered: adults aged 60 years or older attended by PHC for more than 12 months, residing in the urban area and having no cognitive impairment [defined as a score $>5$ in the 10-point cognitive screener (10-CS)]. These inclusion criteria were chosen because we considered it is important to have been adequately attended at a PHC center for a certain period of time to assure the collection of reliable information; significant cognitive impairment can cause problems in selfreported data; also, rural and urban areas have different characteristics, and approximately $85 \%$ of older adults live in urban areas ${ }^{(17-19)}$.

\section{Data collection}

The data collection occurred from July to December 2018. Five researchers were trained by the main researcher for one month before starting the data collection at the units. These researchers contacted the patients while they were waiting for medical consultation, vaccination, wound care, or other health services in the PHC unit ${ }^{(5,15)}$. Interviews were 
carried out in a standardized manner using a questionnaire based on previous elderly cohorts ${ }^{(20,21)}$. Regarding sociodemographic data, we collected information on age, gender, education level (years of formal education), ethnicity (white, black, and others), and living arrangements (living alone or not). Regarding health history, we collected information on self-reported hypertension, depression, and number of medications. In addition, cognitive impairment was evaluated by the $10-\mathrm{CS}$, a validated tool for Brazilian older adults ${ }^{(22)}$.

Health vulnerability was measured using the VES-13 version validated for Brazilian Portuguese ${ }^{(3,23)}$. The VES-13 has 13 items with specific scores: age (1 point for 75-84 years old; 3 points for $\geq 85$ years old), self-rated health status evaluation ( 1 point for bad or regular), physical activity limitations [ 1 point for too much difficulty (or unable) in performing each item, with a maximum score of 2 points. The items were bending, crouching or kneeling; lifting or carrying objects weighing approximately 5 kilograms; raising or extending arms above shoulder level; handling and holding small objects; walking 400 meters; doing heavy house work such as scrubbing floors or cleaning windows], limitations for basic and instrumental activities of daily life (4 points for difficulty in performing one or more item, with a maximum score of 4 points. The items were buying personal items; dealing with money; walking through the room; performing light housework; taking a shower or bath). Thus, the possible VES-13 scores vary from 0 to 10, with higher scores associated with more health vulnerability. Older adults with scores of 3 or more are classically classified as vulnerable ${ }^{(8)}$. However, we used the VES-13 as a continuous variable (from 0 to 10 ) in this study.

The estimated limited life expectancy in 10 years was based on Suemoto index. This index predicts the mortality risk in 10 years for community-dwelling older adults. It uses information on age, gender, self-reported diabetes, heart disease, lung disease, cancer, smoking status, alcohol use, body mass index, physical activity, difficulty with bathing or showering, difficulty with walking several blocks, correctly reporting today's date, and self-reported health status ${ }^{(6)}$. This index reports a predicted mortality in 10 years which varies from 0 to $100 \%$ based on the effect size of each of these variables and mortality in the test cohort. We used the online calculator for the Suemoto index available at e-prognosis (https://eprognosis.ucsf.edu/suemoto.php). We considered that LLE was present when the predicted 10-year mortality risk was $50 \%$ or more. A cut-off of $50 \%$ was used, as previously used in another study related to cancer screening in older adults ${ }^{(12)}$.

\section{Data ANALYSIS}

Numerical variables in the statistical analysis are presented as mean and standard deviations (SD), while categorical variables are expressed as absolute numbers and percentages. The dependent variable was LLE (predicted mortality risk $\geq 50 \%$ calculated by the Suemoto index). The independent variable was the VES-13 score (continuous variable). We compared participants according to the presence of LLE using the chisquared test for categorical variables and unpaired t-test or
Mann-Whitney test for numerical variables. Logistic regression analysis adjusted for age, sex, ethnicity, and education was used to test the association between limited life expectancy and health vulnerability measured by the VES-13. We calculated the area under the Receiver Operating Characteristic (Auroc) curve to determine the discrimination of the VES-13 in identifying individuals with LLE. Additionally, we determined the best VES-13 cut-off with the best accuracy to identify these individuals using the Youden index ${ }^{(24)}$. The Stata 15 software program (College Station, TX: StataCorp LLC) was used for the statistical analysis. The alpha level was set at the $5 \%$ level.

\section{ETHICAL ASPECTS}

The research project was approved by the Ethics and Research Committee with Human Beings of the Fundação de Ensino e Pesquisa em Ciências da Saúde/Secretaria de Saúde/Distrito Federal (Fepecs/SES/DF), under number 2.804.385/2018. Patients received information about this study, and those who agreed to participate and met the eligibility criteria signed the informed consent form.

\section{RESULTS}

A total of 450 older adults were assessed to enroll in this study. However, eight individuals refused to participate, and 35 were excluded due to low scores on the 10-CS. Thus, the study included 407 individuals, in agreement with the sample size calculation. The mean age was $68.9 \pm 6.6$ yo, $58.0 \%$ were women, $60.0 \%$ were non-Caucasian, the mean level of education was $3.6 \pm 3.7$ years, $19.0 \%$ lived alone, $71.0 \%$ had hypertension, $29.0 \%$ had depression, and the mean number of medications was $3.2 \pm 2.1$. The mean score on the VES-13 was $2.0 \pm 2.2$. The mean predicted 10 -year mortality by the Suemoto index was $31.5 \pm 21.1 \%$, and $17.2 \%$ had LLE (Suemoto index $\geq 50 \%$ ).

Sociodemographic and clinical data were compared according to LLE (Table 1). Participants with LLE according to the Suemoto index were older, more frequently males, and had fewer years of formal education than individuals without LLE.

Table 1 - Sample characteristics by limited life expectancy status* - Jataí, GO, Brazil, 2018.

\begin{tabular}{lccc}
\hline & \multicolumn{2}{c}{ Limited Life } & \\
\cline { 2 - 3 } & Expectancy $(\mathbf{n}=\mathbf{4 0 7})$ & p-value \\
\cline { 2 - 3 } & $\mathbf{n}=337$ & $\begin{array}{c}\text { Yes } \\
\mathbf{n}=70\end{array}$ & \\
\hline Age (years), mean (SD) & $67.0(4.8)$ & $77.8(6.3)$ & $<0.0001$ \\
Women, \% & 60.5 & 45.7 & 0.0200 \\
Education (years), mean (SD) ${ }^{\S}$ & $4.1(3.8)$ & $1.4(2.5)$ & $<0.0001$ \\
Ethnicity, \% & & & 0.1400 \\
White & 39.2 & 41.4 & \\
Black & 58.2 & 51.4 & \\
Other & 2.7 & 7.1 & \\
\hline & & & continue...
\end{tabular}




\begin{tabular}{|c|c|c|c|}
\hline & \multicolumn{2}{|c|}{$\begin{array}{c}\text { Limited Life } \\
\text { Expectancy }(n=407)\end{array}$} & \multirow{2}{*}{ p-value } \\
\hline & $\begin{array}{c}\text { No } \\
n=337\end{array}$ & $\begin{array}{c}\text { Yes } \\
\mathrm{n}=70\end{array}$ & \\
\hline Living alone, $\%^{\ddagger}$ & 18.1 & 25.7 & 0.1400 \\
\hline Hypertension, $\%^{\ddagger}$ & 70.5 & 72.9 & 0.7000 \\
\hline Depression, $\%^{\ddagger}$ & 29.4 & 28.6 & 0.8900 \\
\hline $\begin{array}{l}\text { Number of medications, mean } \\
(\mathrm{SD})^{+}\end{array}$ & $3.1(2.5)$ & $3.6(2.4)$ & 0.1400 \\
\hline 10-CS score, mean $(\mathrm{SD})^{+}$ & $7.9(1.3)$ & $7.8(1.3)$ & 0.6500 \\
\hline
\end{tabular}

*Limited life expectancy defined by 10 -year mortality risk $\geq 50 \%$ calculated by the Suemoto Index (J Gerontol A Biol Sci Med Sci. 2017;72(3):410-416).

${ }^{+}$unpaired t-test; ${ }^{\ddagger}$ chi-squared test; ${ }^{\S}$ Mann-Whitney test.

Health vulnerability measured by the VES-13 was associated with LLE predicted by the Suemoto index $(\mathrm{OR}=1.57,95 \% \mathrm{CI}=1.31-1.64, \mathrm{p}<0.0001)($ Table 2$)$.

Table 2-Association between limited life expectancy* and health vulnerability measured by the VES-13 - Jataí, GO, Brazil, 2018.

\begin{tabular}{lccc}
\hline & OR & $\mathbf{9 5 \% ~ C l}$ & $\mathrm{p}$ \\
\hline Simple & 1.47 & $1.31-1.64$ & $<0.0001$ \\
Multiple $^{+}$ & 1.57 & $1.28-1.92$ & $<0.0001$
\end{tabular}

*Limited life expectancy defined by 10 -year mortality risk $\geq 50 \%$ calculated by the Suemoto Index (J Gerontol A Biol Sci Med Sci. 2017;72(3):410-416).

'Logistic regression model adjusted for age, gender, ethnicity, and educational level.

Note: $(n=407)$

The VES-13 showed good discrimination to identify older adults with LLE (AUROC curve $=0.764$, 95\% CI $=0.708-0.820$ ) (Figure 1). The best cut-off of the VES-13 according to the Youden index regarding the accuracy of the VES-13 to detect LLE was $\geq 2$, with a sensitivity of $81 \%$ and specificity of $57 \%$.

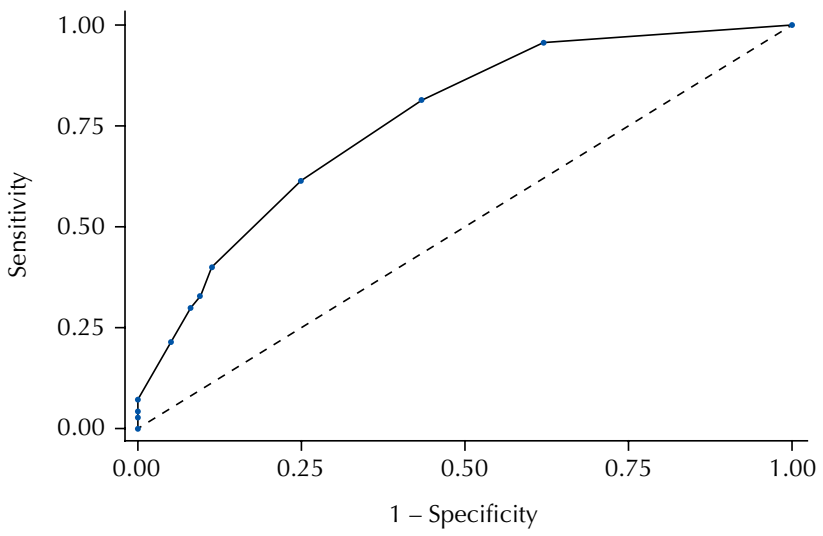

AUROC curve $=0.764(95 \% \mathrm{Cl}=0.708-0.820)$

Note: $(n=407)$

Figure 1 - Area under the receiver operator curve for the VES-13 to detect limited life expectancy.

\section{DISCUSSION}

The main finding of this study was to show that VES13 was associated with LLE in older adults in PHC settings for the first time. In addition, the VES-13 showed good discrimination to detect older adults with LLE according to the Auroc, and a cut-off point $\geq 2$ showed the best accuracy. Detecting patients with possible LLE is important, because these older adults should additionally be evaluated through the Suemoto index to confirm the LLE (10-year mortality risk $\geq 50 \%)$ and then would possibly be advised to discontinue screening (such as colorectal, breast and prostate cancer) and to avoid strict control of chronic diseases (such as diabetes) due to the limited possibility of increasing survival and a high risk of short-term complications ${ }^{(7-11)}$. These screenings and treatments only present potential benefits after many years of medical follow-up.

The VES-13 is already routinely used in the PHC setting in $\mathrm{Brazil}^{(13)}$. Therefore, primary healthcare professionals could promptly use the VES-13 to detect older adults with LLE. Considering the specificity of the VES-13 score $\geq 2$ points was $57 \%$ to detect LLE, individuals with these VES-13 scores should be further evaluated by the Suemoto index to confirm LLE. At this point, it is important to emphasize that the use of two sequential test (as we propose the consecutive use of the VES-13 and Suemoto index to detect LLE) is frequently used in different health scenarios, such as D-dimer testing and computed tomographic pulmonary angiography for pulmonary embolism detection ${ }^{(25)}$. However, future studies should use the VES-13 at baseline and investigate the ability of this tool to predict mortality after 10 years of follow-up.

Regarding the unnecessary cancer screening in older adults with LLE, one should consider the case of colorectal cancer (CRC). CRC is one of the leading causes of cancer mortality, and screening has proven to reduce CRC mortality. Although CRC screening can bring benefits, older individuals should not have LLE, since this type of screening requires 10 years before 1 death related to $\mathrm{CRC}$ can be prevented among 1,000 screened individu$\mathrm{als}^{(12)}$. However, approximately $20-30 \%$ of individuals with LLE inappropriately undergo CRC screening ${ }^{(12,26)}$. Thus, it is very important to provide health professionals with prognosis information (such as LLE), so they can make the best clinical decisions. Furthermore, it is important to keep in mind that CRC screening is associated with a combined adverse event (gastrointestinal perforation or bleeding, cardiovascular events) rate of up to 12.3 per 1,000 screened individuals ${ }^{(27)}$.

The personalized action plan for older adults with LLE in 10 years should go beyond the discussion about the unnecessary cancer screening and strict glycemic control. Primary healthcare professionals should develop collaborative work with gerontologists and geriatricians when treating patients with LLE. All health professionals (i.e. nurses, physicians) working in primary healthcare can increase the sensitivity of screening vulnerable older adults. 
These professionals consider the needs of older adults in the overall health assessment, and can contribute to screening these older adults and refer those who are vulnerable to high complexity to gerontology/geriatric outpatient clinics. This collaborative care would analyze aspects which can be improved to maximize functional independence, quality of life and patient autonomy ${ }^{(5)}$.

Another important point in this study is to emphasize the use of VES-13 as a continuous variable, and not as a categorical variable, as previously used ( $\geq 3$ as vulnerable; $<3$ as non-vulnerable). In three studies (including this one), mortality risk increased with each 1-point increment in the VES-13 score, corroborating the use of this score as a continuous variable ${ }^{(8,28)}$. In addition, scores $\geq 2$ on the VES-13 also detected poor quality of life in older adults in $\mathrm{PHC}^{(5)}$.

Considering the external validity of this study, the characteristics of the older adults included in the present work were similar to those of previous studies ${ }^{(5,15,29)}$. Other studies included older adults with similar characteristics regarding age, gender, education level, and hypertension ${ }^{(5,15)}$. The present study was also similar to another study using the VES-13 regarding age, gender, ethnicity, living arrangements, hypertension, and number of chronic medications ${ }^{(5)}$. Finally, there were similarities regarding the frequencies of gender and depression, and in the age distribution in the study also carried out with older adults in $\mathrm{PHC}^{(29)}$.

This study presents some limitations which should be considered. First, it has a cross-sectional design, and the VES-13 was consequently associated with an LLE estimation, and not the actual 10-year mortality measured during a 10 -year period. However, estimated mortality or estimated adverse event rate is frequently used in clinical practice to decide treatments, as in studies that used the Schonberg index ${ }^{(12)}$. Another questionable point is the cutoff of 50\% of mortality risk to define LLE. However, this cut-off was previously used to define LLE and to decide about cancer screening in older adults ${ }^{(12)}$.

\section{CONCLUSION}

The Vulnerable Elders Survey was able to screen older adults with limited life expectancy in primary healthcare settings. Older adults with VES-13 scores $\geq 2$ should additionally be evaluated through the Suemoto index to confirm the possibility of LLE. The need to use the acquired contributions is emphasized, using them as a subsidy to guide and plan actions which can recognize vulnerable older adults. Thus, this study can help health professionals working in primary healthcare to prioritize the referral of older adults for gerontology/geriatric evaluation and assist managers in planning health services and policies focused on older adults.

The fact that this study only addresses older adults who were in the PHC settings may also have excluded vulnerable older adults who are unable to reach the PHC. As any older adults with cognitive impairment were excluded, this may have resulted in underestimating the prevalence of vulnerable older adults and of LLE. However, further longitudinal studies are needed to attain a better assessment of the role of VES-13 in detecting LLE over 10 years.

\section{RESUMO}

Objetivo: Investigar o potencial do instrumento Vulnerable Elders Survey para identificar idosos com expectativa de vida limitada, em ambientes de atenção primária à saúde. Método: Estudo transversal realizado em todas as (nove) unidades de saúde de Jataí, Goiás (Brasil), no período de julho a dezembro de 2018. Obteve-se uma amostra de 407 idosos, considerando uma população $\geq 60$ anos. Os participantes responderam a um questionário sobre características sociodemográficas e clínicas, incluindo o Vulnerable Elders Survey e o índice de Suemoto. Testamos a associação entre a expectativa de vida limitada e o Vulnerable Elders Survey usando análise de regressão logística múltipla. Resultados: A idade média foi de 68,9 \pm 6,6 anos, e 58,0\% dos participantes eram mulheres. A pontuação média do Vulnerable Elders Survey foi de 2,0 $\pm 2,2$, a pontuação média do índice de Suemoto foi de 31,5 $\pm 21,1 \%$, e 17,2\% dos participantes tinham expectativa de vida limitada. O Vulnerable Elders Survey foi associado a uma expectativa de vida limitada $(\mathrm{OR}=1,57 ; \mathrm{p}=<0,0001)$. Conclusão: O instrumento Vulnerable Elders Survey foi capaz de identificar idosos com expectativa de vida limitada em ambientes de atenção primária à saúde, além de poder auxiliar na detecção de idosos que não se beneficiariam com a triagem e o controle estrito de doenças crônicas.

\section{DESCRITORES}

Idoso; Fragilidade; Programas de Rastreamento; Sensibilidade e Especificidade; Atenção Primária à Saúde.

\section{RESUMEN}

Objetivo: Investigar el potencial del instrumento Vulnerable Elders Survey para identificar adultos mayores con esperanza de vida limitada en centros de atención primaria. Método: Se trata de un estudio transversal realizado en todas las (nueve) unidades sanitarias de Jataí, Goiás (Brasil) de julio a diciembre de 2018. Se consideró una población de $\geq 60$ años, de la cual se obtuvo una muestra de 407 adultos mayores. Los participantes respondieron un cuestionario sobre características sociodemográficas y clínicas, incluyendo el Vulnerable Elders Survey y el índice de Suemoto. Se comprobó la asociación entre la esperanza de vida limitada y el Vulnerable Elders Survey, mediante el análisis de regresión logística múltiple. Resultados: La edad promedio era de 68,9 $\pm 6,6$ años y el $58,0 \%$ de los participantes pertenecía al sexo femenino. La puntuación media del Vulnerable Elders Survey resultó en 2,0 $\pm 2,2 ;$ la puntuación media del índice de Suemoto, $31,5 \pm 21,1 \%$ y el 17,2\% de los participantes tenía una esperanza de vida limitada. El Vulnerable Elders Survey estaba asociado a una esperanza de vida limitada $(\mathrm{OR}=1,57 ; \mathrm{p}=<0,0001)$. Conclusión: El instrumento Vulnerable Elders Survey ha sido capaz de identificar a los adultos mayores con una esperanza de vida limitada en los centros de atención primaria, además de ayudar en la detección de aquellos adultos mayores que no se beneficiarían con el triaje y el control estricto de las enfermedades crónicas.

\section{DESCRIPTORES}

Anciano; Fragilidad; Tamizaje Masivo; Sensibilidad y Especificidad; Atención Primaria de Salud. 


\section{REFERENCES}

1. Brasil. Ministério da Saúde. Portaria n. 2.528, de 19 de outubro de 2006. Aprova a Política Nacional de Saúde da Pessoa Idosa. Diário Oficial da União, Brasília, 20 out. 2006. Seção 1, p. 142.

2. Instituto Brasileiro de Geografia e Estatística. Pesquisa Nacional por Amostra de Domicílios: síntese de indicadores [Internet] . Rio de Janeiro: Instituto Brasileiro de Geografia e Estatística; 2015 [cited 2019 Sep 10]. Available from: https://biblioteca.ibge.gov.br/visualizacao/ livros/liv98887.pdf

3. Saliba D, Elliott M, Rubenstein LZ, Solomon DH, Young RT, Kamberg CJ, et al. The Vulnerable Elders Survey: a tool for identifying vulnerable older people in the community. J Am Geriatr Soc. 2001;49(12):1691-9. https://doi.org/10.1046/j.1532-5415.2001.49281.x

4. Min L, Yoon W, Mariano J, Wenger NS, Elliott MN, Kamberg C, et al. The vulnerable elders-13 survey predicts 5-year functional decline and mortality outcomes in older ambulatory care patients. J Am Geriatr Soc. 2009;57(11):2070-6. https://doi.org/10.1111/j.15325415.2009.02497.x

5. Silva SM, Santana AN, Silva NN, Novaes MR. VES-13 and WHOQOL-bref cutoff points to detect quality of life in older adults in primary health care. Rev Saude Publica. 2019;53:26. https://doi.org/10.11606/S1518-8787.2019053000802

6. Suemoto CK, Ueda P, Beltrán-Sánchez H, Lebrão ML, Duarte YA, Wong R, et al. Development and validation of a 10-year mortality prediction model: meta-analysis of individual participant data from five cohorts of older adults in developed and developing countries. J Gerontol A Biol Sci Med Sci. 2017;72(3):410-6. https://doi.org/10.1093/gerona/glw166

7. Qaseem A, Denberg TD, Hopkins RH Jr, Humphrey LL, Levine J, Sweet DE, et al. Screening for colorectal cancer: a guidance statement from the American College of Physicians. Ann Intern Med. 2012;156(5):378-86. https://doi.org/10.7326/0003-4819-156-5-201203060-00010

8. Qaseem A, Barry MJ, Denberg TD, Owens DK, Shekelle P. Screening for prostate cancer: a guidance statement from the Clinical Guidelines Committee of the American College of Physicians. Ann Intern Med. 2013;158(10):761-9. https://doi.org/10.7326/0003-4819-158-10201305210-00633

9. American Diabetes Association. 11. Older adults: Standards of Medical Care in Diabetes-2018. Diabetes Care. 2018;41 Suppl 1:S119-25. https://doi.org/10.2337/dc18-S011

10. Oeffinger KC, Fontham ET, Etzioni R, Herzig A, Michaelson JS, Shih YC, et al. Breast cancer screening for women at average risk: 2015 guideline update from the American Cancer Society. JAMA. 2015;314(15):1599-614. https://doi.org/10.1001/jama.2015.12783

11. Abdollah F, Sun M, Sammon JD, Choueiri TK, Menon M, Weissman JS, et al. Prevalence of nonrecommended screening for prostate cancer and breast cancer in the United States: a nationwide survey analysis. JAMA Oncol. 2016;2(4):543-5. https://doi.org/10.1001/ jamaoncol.2015.5871

12. Schonberg MA, Breslau ES, Hamel MB, Bellizzi KM, McCarthy EP. Colon cancer screening in U.S. adults aged 65 and older according to life expectancy and age. J Am Geriatr Soc. 2015;63(4):750-6. https://doi.org/10.1111/jgs.13335

13. Brasil. Ministério da Saúde. Secretaria de Atenção à Saúde. Departamento de Ações Programáticas Estratégicas. Caderneta de saúde da pessoa idosa. 4a ed. Brasília: Ministério da Saúde; 2017.

14. Mariano PP, Baldissera VD, Martins JT, Carreira L. Nursing work organization in long-stay institutions for the elderly: relationship to pleasure and suffering at work. Texto Contexto Enferm. 2015;24(3):756-65. https://doi.org/10.1590/0104-070720150-1150014

15. Silva PA, Soares SM, Santos JF, Silva LB. Cut-off point for WHOQOL-bref as a measure of quality of life of older adults. Rev Saude Publica. 2014;48(3):390-7. https://doi.org/10.1590/S0034-8910.2014048004912

16. Moreschi C, Rempel C, Siqueira DF, Backes DS, Pissaia LF, Grave MT. Family Health Strategies: profile/quality of life of people with diabetes. Rev Bras Enferm. 2018;71(6):2899-906. https://doi.org/10.1590/0034-7167-2018-0037

17. Silva LB, Soares SM, Silva PA, Santos JF, Miranda LC, Santos RM. Assessment of the quality of primary care for the elderly according to the Chronic Care Model. Rev Lat Am Enfermagem. 2018;26(0):e2987. https://doi.org/10.1590/1518-8345.2331.2987

18. Silva CS, Barbosa MM, Pinho L, Figueiredo MF, Amaral CO, Cunha FO, et al. Family health strategy: relevance to the functional capacity of older people. Rev Bras Enferm. 2018;71Suppl 2:740-6. https://doi.org/10.1590/0034-7167-2017-0078

19. Garbaccio JL, Tonaco LA, Estêvão WG, Barcelos BJ. Aging and quality of life of elderly people in rural areas. Rev Bras Enferm. 2018;71 Suppl 2:724-32. https://doi.org/10.1590/0034-7167-2017-0149

20. Lebrão ML, Laurenti R. Saúde, bem-estar e envelhecimento: o estudo SABE no Município de São Paulo. Rev Bras Epidemiol. 2005;8(2):127-41. https://doi.org/10.1590/S1415-790X2005000200005

21. Lima-Costa MF, Andrade FB, Souza Junior PR, Neri AL, Duarte YA, Castro-Costa E, et al. The Brazilian Longitudinal Study of Aging (ELSI-Brazil): objectives and design. Am J Epidemiol. 2018;187(7):1345-53. https://doi.org/10.1093/aje/kwx387

22. Apolinario D, Lichtenthaler DG, Magaldi RM, Soares AT, Busse AL, Amaral JR, et al. Using temporal orientation, category fluency, and word recall for detecting cognitive impairment: the 10-point cognitive screener (10-CS). Int J Geriatr Psychiatry. 2016 Jan;31(1):4-12. https://doi.org/10.1002/gps.4282

23. Maia FO, Duarte YA, Secoli SR, Santos JL, Lebrão ML. Cross-cultural adaptation of the Vulnerable Elders Survey-13 (VES-13): helping in the identification of vulnerable older people. Rev Esc Enferm USP. 2012;46(SpecNo):116-22. https://doi.org/10.1590/S008062342012000700017

24. Ruopp MD, Perkins NJ, Whitcomb BW, Schisterman EF. Youden Index and optimal cut-point estimated from observations affected by a lower limit of detection. Biom J. 2008;50(3):419-30. https://doi.org/10.1002/bimj.200710415

25. Konstantinides SV, Torbicki A, Agnelli G, Danchin N, Fitzmaurice D, Galiè N, et al. 2014 ESC guidelines on the diagnosis and management of acute pulmonary embolism. Eur Heart J. 2014;35(43):3033-69. https://doi.org/10.1093/eurheartj/ehu283

26. Mittal S, Lin YL, Tan A, Kuo YF, El-Serag HB, Goodwin JS. Limited life expectancy among a subgroup of medicare beneficiaries receiving screening colonoscopies. Clin Gastroenterol Hepatol. 2014;12(3):443-450.e1. https://doi.org/10.1016/j.cgh.2013.08.021 
27. Warren JL, Klabunde CN, Mariotto AB, Meekins A, Topor M, Brown ML, et al. Adverse events after outpatient colonoscopy in the Medicare population. Ann Intern Med. 2009;150(12):849-57. https://doi.org/10.7326/0003-4819-150-12-200906160-00008

28. Wang J, Lin W, Chang LH. The linear relationship between the Vulnerable Elders Survey-13 score and mortality in an Asian population of community-dwelling older persons. Arch Gerontol Geriatr. 2018;74:32-8. https://doi.org/10.1016/j.archger.2017.09.005

29. Nogueira EL, Rubin LL, Giacobbo SS, Gomes I, Cataldo Neto A. Screening for depressive symptoms in older adults in the Family Health Strategy, Porto Alegre, Brazil. Rev Saude Publica. 2014;48(3):368-77. https://doi.org/10.1590/S0034-8910.2014048004660

(cc) BY This is an open-access article distributed under the terms of the Creative Commons Attribution License. 